\title{
PASSIVE RESTORATION OF MIXED OMBROPHILOUS FOREST A DECADE AFTER FOREST PLANTATION REMOVAL IN THE SOUTH OF BRAZIL
}

\author{
Lilian Iara Bet Stedille ${ }^{1 *}$, Juliano Pereira Gomes ${ }^{2}$, Newton Clóvis Freitas da Costa $^{3}$, Oiéler Felipe Vargas ${ }^{1}$, \\ Lucas da $\mathrm{Luz}^{2}$, Adelar Mantovani ${ }^{2}$ \\ ${ }^{1}$ State University of Santa Catarina, Graduate Program in Forestry, Lages, Santa Catarina, Brasil - lilian.stedille@gmail.com*; \\ oielerfelipe@gmail.com \\ ${ }^{2}$ State University of Santa Catarina, Departament of Forestry, Lages, Santa Catarina, Brasil - julianopgomes@ gmail.com.br, \\ lucasdaluz0@gmail.com, mantovani.a@gmail.com \\ ${ }^{3}$ Federal University of Santa Catarina, Graduate Program in Plant Genetic Resources, Florianópolis, Santa Catarina, Brasil - \\ newtoncfc@gmail.com
}

Received for publication: 19/09/2017 - Accepted for publication: 16/05/2018

\begin{abstract}
The objective of this study was to evaluate the floristic composition, diversity and ecological characteristics of riparian forest tree species under passive restoration a decade after removing Pinus and Eucalyptus genus forest plantations and comparing the data to a reference ecosystem. The study was conducted in a Mixed Ombrophilous Forest fragment in the municipality of Ponte Alta, state of Santa Catarina, Brazil. A total of 30 plots of $200 \mathrm{~m}^{2}$ were installed, 15 in the area under passive restoration and 15 in the reference ecosystem, covering the arboreal and regenerating strata. In these areas, rarefied richness, Shannon index, Pielou evenness, floristic dissimilarity, ecological group representativeness and the tree species dispersal syndromes were evaluated. The families with the highest specific richness were: Myrtaceae (14 species) in the reference ecosystem, and Lauraceae (eight species) in the area under passive restoration. Considering the ecological indicators used and the use of the reference ecosystem, it can be considered that the passive restoration after a decade in forest succession proved to be efficient for enlarging the riparian forests in the studied area.

Keywords: Riparian forest, environmental monitoring, reference ecosystem.
\end{abstract}

\section{Resumo}

Restauração passiva de Floresta Ombrófila Mista após década da retirada de plantios florestais no sul do Brasil. Objetivou-se avaliar a composição florística, diversidade e características ecológicas das espécies arbóreas de matas ciliares em restauração passiva, após uma década da retirada de plantios florestais dos gêneros Pinus e Eucalyptus, comparando os dados a um ecossistema de referência. O estudo foi conduzido em um fragmento de Floresta Ombrófila Mista, no município de Ponte Alta, Santa Catarina, Brasil. Foram instaladas 30 parcelas de $200 \mathrm{~m}^{2}$, sendo 15 na área em restauração passiva e 15 no ecossistema de referência, abrangendo os estratos arbóreo e regenerante. Nessas áreas, foram avaliados a riqueza rarefeita, índice de Shannon, equabilidade de Pielou, dissimilaridade florística, e representatividade dos grupos ecológicos e das síndromes de dispersão das espécies arbóreas. As famílias com maiores riquezas específica foram: Myrtaceae (14 espécies) no ecossistema de referência e Lauraceae (oito espécies) na área em restauração passiva. Considerando os indicadores ecológicos utilizados e o uso do ecossistema de referência, pode-se considerar que, após uma década em sucessão florestal, a restauração passiva mostrou-se eficiente para a ampliação das matas ciliares na área estudada.

Palavras-chave: Matas ciliares, monitoramento ambiental, ecossistema de referência.

\section{INTRODUCTION}

Passive restoration can be described as a technique that recommends a low level of human intervention in the environment, mainly relying on the function of restoring the ecosystem to natural processes and to successional dynamics before suspending or eliminating degradation sources (LETCHER; CHAZDON, 2009; SUDING; HOBBS 2009; REIS et al., 2014). It is considered a viable methodological alternative due to its low cost and high efficiency in sites with fast natural regeneration, generally linked to a scenario with a landscape matrix having connectivity (RODRIGUES et al., 2015).

The presence of adjacent forest fragments is essential, since even in secondary formation these are responsible for ensuring propagule sources, as well as the presence and quantity of dispersing agents, which consequently promote species recruitment (CIELO-FILHO; SOUZA, 2016). Over time, it is possible to establish functional connectivity and gene flow between the adjacent fragments and the sites to be restored

FLORESTA, Curitiba, PR, v. 48, n. 4, p. 523-534, out/dez. 2018

Stedille. L. I. B. et.al.

ISSN eletrônico 1982-4688

DOI: $10.5380 /$ rf.v48i4.55319 
(LETCHER; CHAZDON, 2009), thereby providing the re-establishment of a series of processes of the system as a whole and generating a diversity of natural flows (SUDING; HOBBS, 2009; REIS et al., 2014).

Passive restoration is the most used method for recovering anthropized environments throughout the world (MELI et al., 2017). In the Mixed Ombrophilous Forest this methodology is able to reincorporate high species richness in areas previously occupied by forest plantations, spontaneously promoting the return of ecological interactions of plant and animal communities in the ecosystem (FERREIRA et al., 2012; FERRACIN et al. 2013; SCARIOT et al., 2014).

The evaluation of fragments in the secondary stage, called ecological reference, in the same landscape matrix, enables conducting comparative studies with the sites to be restored (RUSCHEL et al. 2009; SUGANUMA et al., 2013), in addition to making it possible to obtain ecological reference variables, called ecological indicators according to Rodrigues et al. (2015). Among the reference variables, we highlight species composition, associated dispersion syndromes, ecological groups, forest structure and species diversity (SCHORN et al. 2013; FERRACIN et al. 2013; CIELO-FILHO; SOUZA, 2016).

In Brazil, conducting passive restoration along with its guidelines described in Resolution No. 429 of CONAMA (2011) are indicated for riparian forest restoration. On the one hand, Schorn et al. (2013) consider that a tested and efficient methodology for restoring riparian forests in the Mixed Ombrophilous Forest as non-existent. On the other hand, pioneering studies guide the use of forest succession (passive restoration) in riparian forests used in the past with silvicultural activities, and show the potential of this methodology (REIS et al., 2007; FERREIRA et al., 2012; SCARIOT et al., 2014).

The objective of this study was to evaluate the floristic composition, diversity and ecological characteristics of riparian forest tree species under passive restoration a decade after removing forest plantations (species of the Eucalyptus and Pinus genus). Posteriorly, comparing them to a reference ecosystem and answer the following questions: (1) Do the sites under passive restoration in Mixed Ombrophilous Forest present similar tree floristic composition and species diversity to the reference ecosystem? (2) Is there species incorporation of more advanced successional stages in the regenerating stratum of the restoration area in comparison to the arboreal stratum?

\section{MATERIAL AND METHODS}

It has a mean altitude of $880 \mathrm{~m}$ and a humid subtropical mesothermic $\mathrm{Cfb}$ climate (Köppen-Geiger classification), with an average temperature of the hottest months below $22^{\circ} \mathrm{C}$, and annual precipitation around 1,600 to 1,900 mm (ALVARES et al., 2014). The soil is Cambisol Haplic with a clayey texture (EMBRAPA, 2013) and undulated relief to smooth undulation (FERREIRA et al., 2012). The study area is composed of two riparian forest environments, namely: sector one (S1) - ecological reference with 176 ha; and sector two (S2) - forest under passive restoration of 88 ha. 


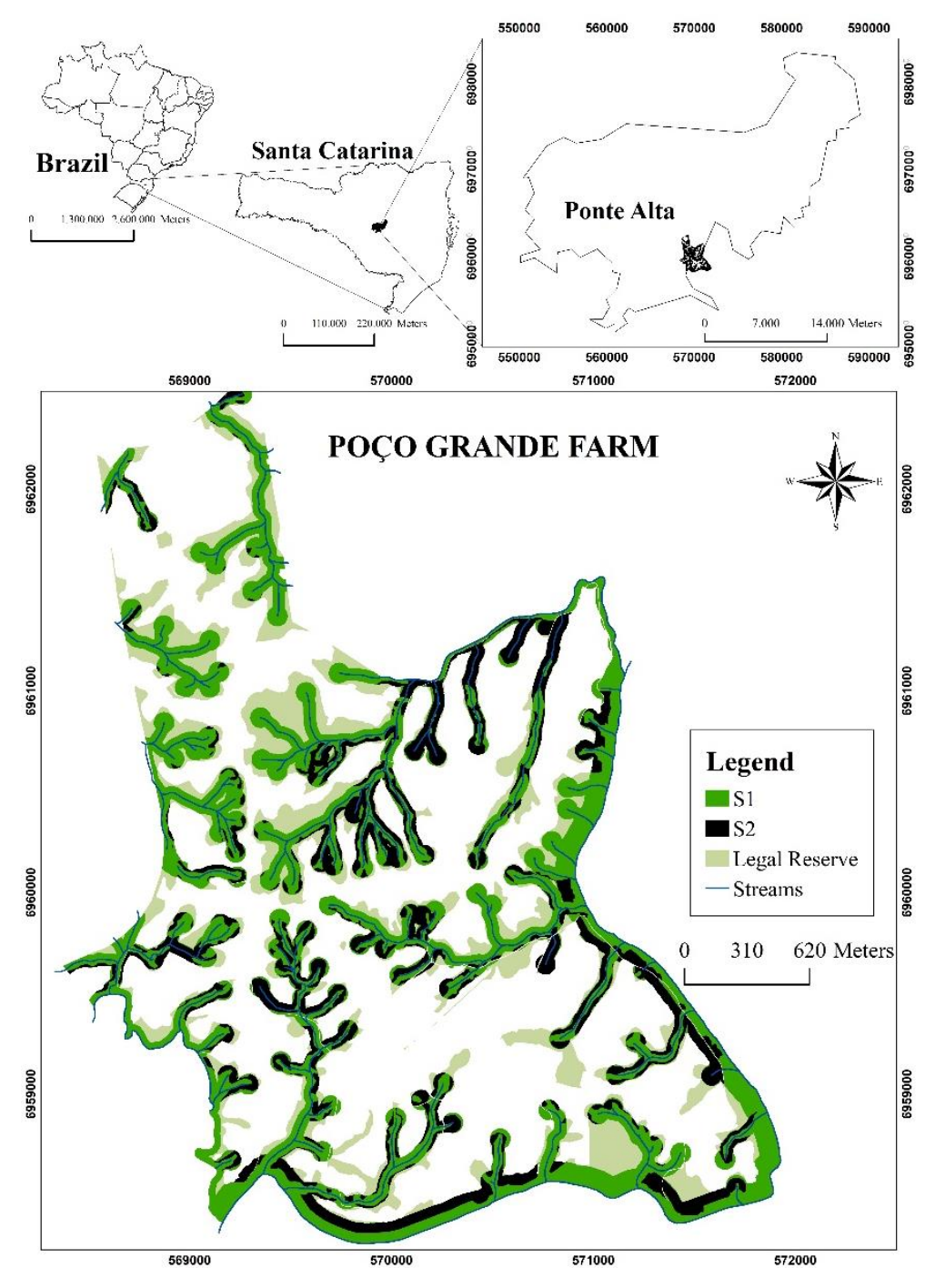

Figure 1. Map of the study area and evaluated sectors (S1 - reference ecosystem and S2 - passive restoration), at the silvicultural Poço Grande Farm, municipality of Ponte Alta, state of Santa Catarina, Brazil.

Figura 1. Mapa da área de estudo e setores avaliados (S1 - ecossistema de referência e S2 - restauração passiva), na fazenda silvícola Poço Grande, município de Ponte Alta, Santa Catarina, Brasil.

Historically, S1 sector areas have undergone selective logging cycles, which has not happened for approximately 40 years. In the S2 sector, native vegetation cover was replaced by plantations with commercial forest species around 1965, mainly Pinus and (less expressive) Eucalyptus. In order to promote riparian forest expansion, commercial species were mechanically extracted and degradation sources (domestic animals and initial control of invasive species) were eliminated after two cultivation cycles. Since then, the vegetation has been under natural regeneration for at least ten years. Both sites were classified according to vegetation characteristics, land use maps and current and historical aerial photographs. In addition to the riparian forest environments, the property has 103 ha of Legal Reserve in different stages of succession.

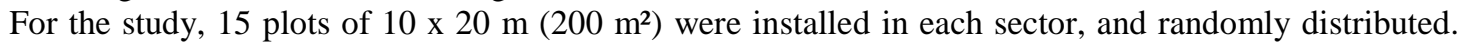
Among them, ten comprised the arboreal stratum sample of each sector [individuals with circumference at breast height $(\mathrm{CBH})$, measured at $1.30 \mathrm{~m}$ above ground level, $\geq 15.7 \mathrm{~cm}]$. The regenerating stratum was evaluated in the other plots (individuals of tree species with height $\geq 10$ and $<150 \mathrm{~cm}$ ). In addition to the angiosperm and gymnosperm species, pteridophytes, which are commonly sampled in this phytophysiognomy, were included in both strata. We carried out species identification based on herbarium exsiccates, specialized literature and by consulting specialists, and the spelling of the scientific names is based on the List of species of Brazilian flora (FLORA DO BRASIL 2020; FLORA DO BRASIL, 2018). For young plants, the identifications were based on dendrological characteristics and on comparisons with a survey made on the same property by

FLORESTA, Curitiba, PR, v. 48, n. 4, p. 523-534, out/dez. 2018

Stedille. L. I. B. et.al.

ISSN eletrônico 1982-4688

DOI: $10.5380 /$ rf.v48i4.55319 
Ferreira et al. (2012). The collections with reproductive structures were deposited in the Lages Herbarium of the State University of Santa Catarina (LUSC) and the non-reproductive collections (young plants) were stored in the Forest Ecology Laboratory of the State University of Santa Catarina.

To describe the ecological indicators, the species were classified into ecological groups (EG) according to Budowski (1965), and dispersion syndromes (DS) according to Van der Pijl (1972), through field observations, diaspore characteristics and consultations, especially by Reitz et al. (1978) and Giehl et al. (2007). Relative participation of species and individuals in the EG and DS was analyzed by the proportion test $(p \leq 0.05)$ between sectors for each EG or DS in relation to the total sampled. The diversity in the strata of each sector was subsequently evaluated by the Shannon index $\left(\mathrm{H}^{\prime}\right)$, evenness by the Pielou index $\left(\mathrm{J}^{\prime}\right)$, and a comparison of the Shannon index was performed by the Hutcheson t-test.

The sample intensity was verified by the values obtained in the average curve of species accumulation using the permutational method as based on the species/area ratio. Standardized wealth estimation was determined using a rarefaction curve, allowing a comparison of wealth among the evaluated sectors.

We evaluated the existence of floristic-structural patterns by the Non-Metric Multidimensional Scaling (NMDS) method and by the Bray-Curtis index, followed by the STandardized REsidual Sum of Squares (STRESS) analysis value. Significant differences in the floristic-structural composition of the sectors for each stratum were subsequently verified using Permutational Multivariate Analysis of Variation (PERMANOVA). The R statistical program was used for these analyses (R DEVELOPMENT CORE TEAM, 2016).

\section{RESULTS}

A total of 89 species were sampled, constituents of the arboreal and regenerating strata belonging to 60 genera and 35 botanical families (Table 1). It was not possible to identify two individuals of the S1 sector tree stratum in this study.

Table 1. Floristic survey of the arboreal (ARB) and regenerating (REG) stratum, followed by abundance, sectors of reference ecosystem (S1) and passive restoration (S2), registered in the Herbarium Lages of the State University of Santa Catarina (RH), ecological group (EG), and dispersion syndrome (DS), sampled in riparian forests, Mixed Ombrophilous Forest, municipality of Ponte Alta, state of Santa Catarina, Southern Brazil.

Tabela 1. Florística do estrato arbóreo (ARB) e regenerante (REG), seguida da abundância, setores de referência ecológica (S1) e restauração passiva (S2), registro no Herbário Lages da Universidade do Estado de Santa Catarina (RH), grupo ecológico (GE) e síndrome de dispersão (SD), amostrada em matas ciliares, Floresta Ombrófila Mista, município de Ponte Alta, Santa Catarina, Brasil.

\begin{tabular}{|c|c|c|c|c|c|c|c|c|}
\hline \multirow{2}{*}{ Family } & \multirow{2}{*}{ Species } & \multicolumn{2}{|c|}{ ARB } & \multicolumn{2}{|c|}{ REG } & \multirow{2}{*}{ RH } & \multirow{2}{*}{ EG } & \multirow{2}{*}{ DS } \\
\hline & & S1 & $\mathbf{S 2}$ & S1 & $\mathbf{S 2}$ & & & \\
\hline Anacardiaceae & Schinus terebinthifolius Raddi & 2 & - & - & 1 & 8205 & Is & Zoo \\
\hline Annonaceae & Annona rugulosa (Schltdl.) H.Rainer & - & - & - & 1 & - & Is & Zoo \\
\hline \multirow[t]{4}{*}{ Aquifoliaceae } & Ilex dumosa Reissek & - & - & - & 1 & - & Is & Zoo \\
\hline & Ilex microdonta Reissek & - & - & - & 2 & - & Is & Zoo \\
\hline & Ilex paraguariensis A. St. Hill. & 8 & 4 & 74 & 18 & 8204 & $\mathrm{Pi}$ & Zoo \\
\hline & Ilex theezans Mart. ex Reissek & 1 & 1 & 1 & - & - & Is & Zoo \\
\hline Araucariaceae & Araucaria angustifolia (Bertol.) Kuntze & 1 & - & 1 & 2 & 8209 & $\mathrm{Pi}$ & Zoo \\
\hline \multirow[t]{6}{*}{ Asteraceae } & Baccharis semiserrata DC. & - & - & - & 9 & - & $\mathrm{Pi}$ & Ane \\
\hline & Baccharis sp. & - & - & - & 1 & - & $\mathrm{Pi}$ & Ane \\
\hline & Baccharis uncinella DC. & - & - & - & 2 & - & $\mathrm{Pi}$ & Ane \\
\hline & Piptocarpha angustifolia Dusén ex Malme & 6 & 34 & - & 4 & 8157 & $\mathrm{Pi}$ & Ane \\
\hline & $\begin{array}{c}\text { Symphyopappus compressus (Gardner) } \\
\text { B.L.Rob. }\end{array}$ & - & 1 & - & - & 8176 & $\mathrm{Pi}$ & Ane \\
\hline & Vernonanthura discolor (Spreng.) H.Rob. & 12 & 9 & 2 & 10 & 8203 & $\mathrm{Pi}$ & Ane \\
\hline Bignoniaceae & Jacaranda puberula Cham. & - & 4 & - & 2 & 2678 & $\mathrm{Pi}$ & Aut \\
\hline
\end{tabular}




\begin{tabular}{|c|c|c|c|c|c|c|c|c|}
\hline Canellaceae & Cinnamodendron dinisii Schwacke & - & - & 1 & 1 & - & $\mathrm{Pi}$ & Zoo \\
\hline Cannabaceae & Celtis iguanaea (Jacq.) Sarg. & - & - & 1 & - & - & Is & Zoo \\
\hline Cardiopteridaceae & Citronella gongonha (Mart.) R.A. Howard & - & - & 3 & - & - & Is & Zoo \\
\hline Clethraceae & Clethra scabra Pers. & 4 & 1 & 1 & 54 & 8202 & $\mathrm{Pi}$ & Aut \\
\hline \multirow[t]{2}{*}{ Cunoniaceae } & Lamanonia ternata Vell. & - & - & 1 & - & - & Is & Ane \\
\hline & Weinmannia paulliniifolia Pohl ex Ser. & - & - & 1 & - & - & Is & Aut \\
\hline Cyatheaceae & Alsophila setosa Kaulf. & 2 & 1 & - & - & 8201 & Cli & Ane \\
\hline Dicksoniaceae & Dicksonia sellowiana Hook. & 53 & 6 & 45 & 17 & 8208 & $\mathrm{Cl}$ & Ane \\
\hline Erytroxylaceae & Erythroxylum deciduum A.St.-Hil. & - & - & - & 1 & - & Is & Zoo \\
\hline \multirow[t]{2}{*}{ Euphorbiaceae } & Gymnanthes klotzschiana Müll. Arg. & 3 & 1 & 19 & 7 & 2689 & Is & Aut \\
\hline & Sapium glandulosum (L.) Morong & - & - & - & 1 & - & Is & Zoo \\
\hline \multirow[t]{5}{*}{ Fabaceae } & Dalbergia frutescens (Vell.) Britton & 1 & - & 28 & 1 & - & Is & Ane \\
\hline & Inga lentiscifolia Benth. & 10 & - & 26 & 2 & 8199 & Is & Zoo \\
\hline & Machaerium paraguariense Hassl. & - & - & 1 & - & - & Is & Ane \\
\hline & Mimosa scabrella Benth. & 20 & 92 & - & 56 & 8156 & $\mathrm{Pi}$ & Aut \\
\hline & $\begin{array}{l}\text { Muellera campestris (Mart. ex Benth.) M.J. } \\
\text { Silva \& A.M.G. Azevedo }\end{array}$ & - & - & 2 & - & - & Is & Ane \\
\hline \multirow[t]{9}{*}{ Lauraceae } & Cinnamoтиm атоепит (Nees) Kosterm. & - & 1 & 2 & 18 & 8196 & Is & Zoo \\
\hline & Cinnamomum glaziovii (Mez) Kosterm & - & 1 & - & - & 8194 & $\mathrm{Cl}$ & Zoo \\
\hline & Cryptocarya aschersoniana $\mathrm{Mez}$ & 13 & - & 5 & - & 8195 & Ls & Zoo \\
\hline & Ocotea puberula (Rich.) Nees & 1 & 7 & - & 9 & 8165 & $\mathrm{Pi}$ & Zoo \\
\hline & Ocotea pulchella (Nees \& Mart.) Mez & 2 & - & 3 & 10 & 8164 & $\mathrm{Pi}$ & Zoo \\
\hline & Nectandra grandiflora Nees & - & - & - & 3 & - & Ls & Zoo \\
\hline & Nectandra lanceolata Nees & 4 & 1 & - & - & - & Is & Zoo \\
\hline & Nectandra megapotamica (Spreng.) Mez & - & - & 2 & 1 & 2680 & Is & Zoo \\
\hline & Persea major (Meisn.) L.E.Kopp & - & - & 2 & 2 & - & $\mathrm{Cl}$ & Zoo \\
\hline Malvaceae & Luehea divaricata Mart. \& Zucc. & - & - & 1 & - & - & Is & Ane \\
\hline Melastomataceae & Miconia sp. & - & - & 1 & - & - & Is & Zoo \\
\hline Meliaceae & Cedrela fissilis Vell. & 2 & 4 & 1 & - & 2681 & Is & Ane \\
\hline \multirow[t]{14}{*}{ Myrtaceae } & Blepharocalyx salicifolius (Kunth) O. Berg & - & - & 5 & - & - & Is & Zoo \\
\hline & Calyptranthes concinna DC. & 3 & - & - & 49 & - & Is & Zoo \\
\hline & Campomanesia rhombea O.Berg & - & - & 13 & - & - & Is & Zoo \\
\hline & Campomanesia xanthocarpa Mart. ex O. Berg & 1 & - & 3 & - & 2683 & Is & Zoo \\
\hline & Eugenia burkartiana (D.Legrand) D. Legrand & - & - & 33 & - & - & Ls & Zoo \\
\hline & Eugenia pluriflora DC. & - & - & 23 & - & - & Is & Zoo \\
\hline & Eugenia subterminalis DC. & 1 & - & - & - & 8189 & Is & Zoo \\
\hline & Myrcia hatschbachii D.Legrand & 1 & - & - & - & - & Is & Zoo \\
\hline & Myrcia oblongata DC. & - & - & 1 & - & - & Is & Zoo \\
\hline & Myrcia palustris DC. & 1 & - & - & - & - & Is & Zoo \\
\hline & Myrcia splendens (Sw.) DC. & 1 & 2 & 11 & 2 & 8190 & Is & Zoo \\
\hline & $\begin{array}{l}\text { Myrceugenia miersiana (Gardner) D. Legrand } \\
\text { \& Kausel }\end{array}$ & 5 & - & - & - & 8192 & Is & Zoo \\
\hline & Myrceugenia myrcioides (Cambess.) O.Berg & 11 & - & 89 & - & 8191 & $\mathrm{Cl}$ & Zoo \\
\hline & Myrciaria delicatula (DC.) O.Berg & - & - & 6 & - & - & Is & \\
\hline
\end{tabular}

FLORESTA, Curitiba, PR, v. 48, n. 4, p. 523-534, out/dez. 2018 


\begin{tabular}{|c|c|c|c|c|c|c|c|c|}
\hline Picramniaceae & Picramnia parvifolia Engl. & - & - & 2 & - & - & Is & Zoo \\
\hline Pinaceae & Pinus taeda $\mathrm{L}$. & - & 2 & - & 3 & 8187 & $\mathrm{Pi}$ & Ane \\
\hline \multirow[t]{2}{*}{ Primulaceae } & $\begin{array}{c}\text { Myrsine coriacea (Sw.) R. Br. ex Roem. \& } \\
\text { Schult. }\end{array}$ & 11 & 14 & 1 & 21 & 8206 & $\mathrm{Pi}$ & Zoo \\
\hline & Myrsine umbellata Mart. & - & - & 2 & - & - & Is & Zoo \\
\hline Proteaceae & Roupala montana Aubl. & - & 1 & 1 & - & - & Is & Ane \\
\hline Rosaceae & Prunus myrtifolia (L.) Urb. & - & - & 3 & 22 & 2697 & Is & Zoo \\
\hline Rubiaceae & Coutarea hexandra (Jacq.) K. Schum. & - & - & 2 & - & - & Is & Ane \\
\hline Rutaceae & Zanthoxylum rhoifolium Lam. & - & - & 1 & - & - & Is & Zoo \\
\hline \multirow[t]{3}{*}{ Salicaceae } & Banara tomentosa Clos & - & - & 6 & - & - & Ls & Zoo \\
\hline & Casearia decandra Jacq. & 2 & 1 & 51 & 1 & 8186 & Is & Zoo \\
\hline & Casearia obliqua Spreng. & 1 & - & 8 & - & - & Is & Zoo \\
\hline \multirow[t]{4}{*}{ Sapindaceae } & $\begin{array}{c}\text { Allophylus edulis (A.St.-Hil. et al.) Hieron. ex } \\
\text { Niederl. }\end{array}$ & 3 & - & 45 & 2 & 2699 & Is & Zoo \\
\hline & Allophylus guaraniticus (A. St.-Hil.) Radlk. & - & - & 71 & - & - & Ls & Zoo \\
\hline & Cupania vernalis Cambess & 3 & - & - & - & 8184 & Ls & Zoo \\
\hline & Matayba elaeagnoides Radlk. & 11 & 3 & 81 & 28 & 8185 & Is & Zoo \\
\hline \multirow[t]{7}{*}{ Solanaceae } & Aureliana fasciculata (Vell.) Sendtn. & 1 & 3 & - & - & 8183 & $\mathrm{Pi}$ & Zoo \\
\hline & Cestrum corymbosum Schltdl. & - & 1 & - & - & 8210 & $\mathrm{Pi}$ & Zoo \\
\hline & Solanum sp. & - & - & 1 & - & - & $\mathrm{Pi}$ & Zoo \\
\hline & Solanum pseudoquina A. St.Hill & - & 2 & - & - & 8182 & $\mathrm{Pi}$ & Zoo \\
\hline & Solanum lacerdae Dusén & - & - & - & 2 & - & $\mathrm{Pi}$ & Zoo \\
\hline & Solanum mauritianum Scop. & - & - & - & 3 & - & Is & Zoo \\
\hline & Solanum variabile Mart. & 1 & 4 & - & 23 & 2685 & Is & Zoo \\
\hline Styracaceae & Styrax leprosus Hook. \& Arn. & 1 & - & 14 & 7 & 8180 & Is & Zoo \\
\hline \multirow[t]{2}{*}{ Symplocaceae } & Symplocos tenuifolia Brand & 43 & 1 & - & - & 8181 & Is & Zoo \\
\hline & Symplocos uniflora (Pohl) Benth. & - & - & 1 & - & - & Is & Zoo \\
\hline Winteraceae & Drimys brasiliensis Miers & 2 & - & - & - & 2687 & Ls & Zoo \\
\hline
\end{tabular}

In which: Pi: pioneer; Is: initial secondary; Ls: late secondary; Cl: climax; Ane: anemochoric; Aut: autochoric; Zoo: zoochoric.

Figure 2 shows the species of highest importance value that compose the tree stratum for each sampled area.
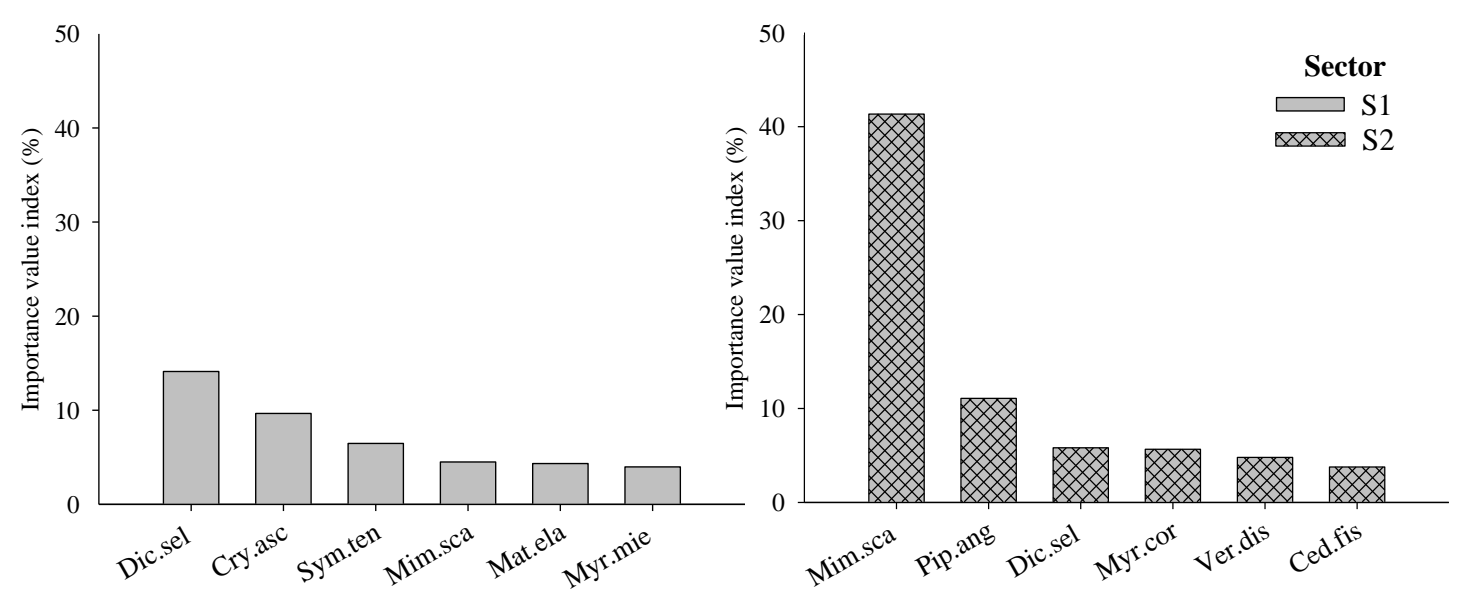
In which: S1: reference ecosystem; S2: passive restoration; Dic.sel: Dicksonia sellowiana; Cry.asc: Cryptocarya aschersoniana; Sym.ten: Symplocos tenuifolia; Mim.sca: Mimosa scabrella; Mat.ela: Matayba elaeagnoides; Myr.mie: Myrceugenia miersiana; Pip.ang: Piptocarpha angustifolia; Myr.cor: Myrsine coriacea; Ver.dis: Vernonanthura discolor; Ced.fis: Cedrela fissilis.

Figure 2. Importance value of the main representative species of the arboreal stratum in descending order for both evaluated sectors in a riparian Mixed Ombrophilous Forest, municipality of Ponte Alta, state of Santa Catarina, Southern Brazil.

Figura 2. Valor de importância das principais espécies representantes do estrato arbóreo em ordem decrescente para os dois setores avaliados, em uma mata ciliar da Floresta Ombrófila Mista, Ponte Alta, Santa Catarina, Brasil.

The comparisons of the ecological indicators between sectors and the sample intensity are presented in Table 2. The sample adequacy was achieved with adherence to the criterion proposed by Cain and Castro (1959) for both sectors and in both strata, where the increase of $10 \%$ in sample area did not surpass the inclusion of $10 \%$ of new species. Sample intensity values are presented in Table 2.

Table 2. Ecological indicators of a riparian Mixed Ombrophilous Forest, municipality of Ponte Alta, state of Santa Catarina, Southern Brazil.

Tabela 2. Indicadores ecológicos de uma mata ciliar, Floresta Ombrófila Mista, município de Ponte Alta, Santa Catarina, Brasil.

\begin{tabular}{|c|c|c|c|}
\hline Ecological indicators & S1 & S2 & $p$ \\
\hline Species richness (Abundance of individuals) ARB & $39(250)$ & $28(202)$ & \\
\hline Species richness (Abundance of individuals) REG & $50(698)$ & 38 (399) & \\
\hline Rarefied richness of ARB \pm standard error ${ }^{*}$ & $37.64 \pm 1.08$ & $28.00 \pm 0.00$ & \\
\hline Rarefied richness of REG \pm standard error* & $35.66 \pm 2.66$ & $34.63 \pm 2.10$ & \\
\hline Shannon Index (nats ind ${ }^{-1}$ ) ARB & 2.86 & 2.09 & $<0.01^{1}$ \\
\hline Shannon Index (nats ind ${ }^{-1}$ ) REG & 2.99 & 2.91 & $\mathrm{~ns}^{1}$ \\
\hline Pielou Evenness - J' ARB & 0.78 & 0.63 & \\
\hline Pielou Evenness - J' REG & 0.76 & 0.80 & \\
\hline
\end{tabular}

Ecological Group - individuals ( $\%$ in relation to the total per sector) (the rest not significant) ${ }^{2}$

Stratum ARB, pioneer

Stratum REG, pioneer

$66(26.6 \%) \quad 174(86.1 \%) \quad<0.01^{2}$

$84(11.2 \%) \quad 204(58.3 \%) \quad<0.01^{2}$

$\begin{array}{llll}\text { Stratum ARB, initial secondary } & 98(39.5 \%) & 20(9.9 \%) & <0.01^{2}\end{array}$

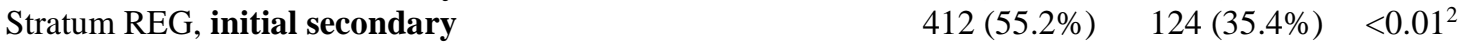

Stratum ARB, late secondary $\quad 18(7.3 \%) \quad 0 \quad<0.01^{2}$

Stratum REG, late secondary $\quad 115(15.4 \%) \quad 19(5.4 \%)<0.01^{2}$

Stratum ARB, climax $\quad 66(26.6 \%) \quad 8(4.0 \%) \quad<0.01^{2}$

Stratum REG, climax $\quad 136(18.2 \%) \quad 3(0.9 \%) \quad<0.01^{2}$

Ecological group - species (\% in relation to the total per sector) (the rest not significant) ${ }^{2}$

$\begin{array}{llll}\text { Stratum REG, pioneer } & 8(16.0 \%) & 16(42.1 \%) & 0.010^{2}\end{array}$

Dispersion Syndrome - individuals ( $\%$ in relation to the total per sector) (the rest not significant) ${ }^{2}$

$\begin{array}{llll}\text { Stratum ARB, zoochoric } & 145(58.5 \%) & 46(22.8 \%) & <0.01^{2}\end{array}$

$\begin{array}{llll}\text { Stratum REG, zoochoric } & 642(85.9 \%) & 184(52.6 \%) & <0.01^{2}\end{array}$

Stratum ARB, autochoric $\quad 27(10.9 \%) \quad 98(48.5 \%)<0.01^{2}$

$\begin{array}{llll}\text { Stratum REG, autochoric } & 21(2.8 \%) & 119(34.0 \%) & <0.01^{2}\end{array}$

Dispersion Syndrome - species ( $\%$ in relation to the total per sector) (the rest not significant) ${ }^{2}$

\begin{tabular}{llll} 
Stratum REG, zoochoric & $37(74.0 \%)$ & $26(68.4 \%)$ & $<0.01^{2}$ \\
\hline
\end{tabular}

\section{SAMPLE INTENSITY}

$\%$ ARB species with the addition of $10 \%$ of sample area $\quad 3.61 \quad 5.46$

$\%$ REG species with the addition of $10 \%$ of sample area $\quad 5.60 \quad 5.34$

In which: S1: reference ecosystem; S2: passive restoration; ARB: arboreal stratum; REG: regenerating stratum; $p$ : test significance; ns: not significant; ; : abundance limit for construction of the rarefaction curve of 205 individuals; ${ }^{1}$ : Hutcheson t-test; ${ }^{2}$ : test of proportions.

The floristic-structural dissimilarity was high among the sector plots, with significant floristic-structural distance and ratified by PERMANOVA $(\mathrm{p}<0.01)$. Interpretation of results by NMDS is possible because STRESS values are less than 0.2 .

FLORESTA, Curitiba, PR, v. 48, n. 4, p. 523-534, out/dez. 2018

Stedille. L. I. B. et.al.

ISSN eletrônico 1982-4688

DOI: $10.5380 /$ rf.v48i4.55319 

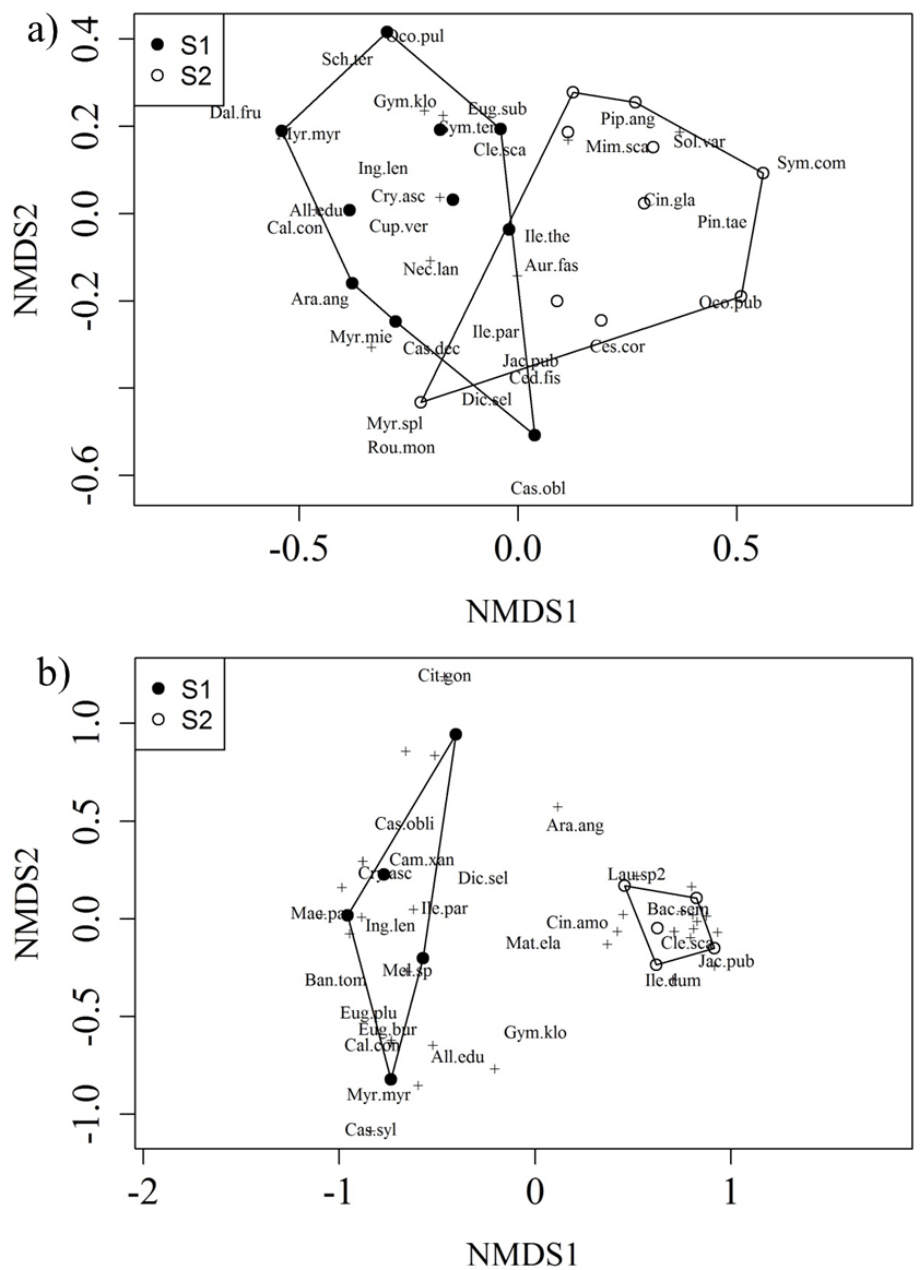

In which: S1: reference ecosystem; S2: passive restoration; All.edu: Allophylus edulis; Ara.ang: Araucaria angustifolia; Aur.fas: Aureliana fasciculata; Bac.sem: Baccharis semiserrata; Ban.tom: Banara tomentosa; Cal.con: Calyptranthes concinna; Cam.xan: Campomanesia xanthocarpa; Cas.dec: Casearia decandra; Cas.obl: Casearia obliqua; Ced.fis: Cedrela fissilis; Ces.cor: Cestrum corymbosum; Cin.amo: Cinnamomum amoenum; Cin.gla: Cinnamomum glaziovii; Cle.sca: Clethra scabra; Cry.asc: Cryptocarya aschersoniana; Cup.ver: Cupania vernalis; Dal.fru: Dalbergia frutescens; Dic.sel: Dicksonia sellowiana; Eug.bur: Eugenia burkartiana; Eug.plu: Eugenia pluriflora; Eug.sub: Eugenia subterminalis; Gym.klo: Gymnanthes klotzschiana; Ile.dum: Ilex dumosa; Ile.par: Ilex paraguariensis; Ile.the: Ilex theezans; Ing.len: Inga lentiscifolia; Jac.pub: Jacaranda puberula; Mac.par: Machaerium paraguariense; Mat.ela: Matayba elaeagnoides; Mel.sp: Miconia sp.; Mim.sca: Mimosa scabrella; Myr.mie: Myrceugenia miersiana; Myr.myr: Myrceugenia myrcioides; Myr.spl: Myrcia splendens; Nec.lan: Nectandra lanceolata; Oco.pub: Ocotea puberula; Oco.pul: Ocotea pulchella; Pin.tae: Pinus taeda; Pip.ang: Piptocarpha angustifolia; Rou.mon: Roupala montana; Sch.ter: Schinus terebinthifolius; Sol.var: Solanum variabile; Sym.com: Symphyopappus compressus; Sym.ten: Symplocos tenuifolia.

Figure 3. Non-metric Multidimensional Scaling (NMDS) for plots and sampled species; (a) arboreal stratum and (b) regeneration stratum, sectors $\mathrm{S} 1$ and $\mathrm{S} 2$.

Figura 3. Escalonamento Multidimensional Não Métrico (NMDS) para parcelas e espécies amostradas; (a) estrato arbóreo e (b) estrato regenerante, setores S1 e S2.

\section{DISCUSSION}

In the reference ecosystem (S1), Myrtaceae stood out as the richest family with 14 species; a fact quite common in surveys carried out in Mixed Ombrophilous Forests, mainly in mature secondary forests (SIMINSKI et al., 2011; VIBRANS et al., 2011; FERREIRA et al., 2012). In the S2 sector, Myrtaceae was not a very expressive family, with the general species Myrcia splendens (Sw.) DC. as its only representative. The most representative botanical family in this sector was Lauraceae, which is also commonly sampled in this phytophysiognomy (REITZ et al., 1978; VIBRANS et al., 2011).

Due to the fact that Myrtaceae is characterized as a family with exclusive zoochoric dispersion syndrome (GRESSLER et al., 2006), a possible failure in the arrival of propagules, in the recruitment of species and/or in the establishment of individuals of this family for sector S2 were first suggested. However, the study by Scariot et al. (2014) corroborates the results obtained in this study, in which Myrtaceae was not an expressive 
family. No species of the family were sampled after two decades of passive restoration in an area previously used for forest plantations. Thus, we consider that the species incorporation of this family in the forest is gradual and the short period in forest succession (a decade) is not enough to allow greater participation of the family. We emphasize that other factors may be influencing this process, such as the absence of ecological corridors, as well as dispersing agents, landscape connectivity, or abiotic characteristics of the site.

Among the evaluated species, Pinus taeda deserves to be highlighted, and can be considered a threat to biodiversity due to its invasive nature in open areas of Mixed Ombrophilous Forest (EMER; FONSECA, 2011). This was the only species of the arboreal composition that presents invasive character and only occurred in the S2 sector. This highlights the importance of monitoring the restoration process, which enables indicating the need for intervention and managing the environment. In this case, it acts as an eliminator of a future source of propagules in the environment when these individuals reach the reproductive stage.

Throughout the successional process, there is a tendency of an increase in the proportion of more demanding individuals in environmental conditions, mainly propitiated by the lower light incidence. Thus, the greatest abundance of pioneer individuals, as observed in S2 (Table 2), has the function of preparing the environment for climatic species, since pioneer species naturally have an early senescence, playing the role of facilitator in the successional process (REIS et al., 2007). With the natural death of pioneer species individuals and the consequent decrease of density, they become less frequent starting from 15 years of the forest (RUSCHEL et al., 2009; SIMINSKI et al., 2011).

In addition to abundance, the $\mathrm{S} 2$ sector obtained the highest proportion of pioneer species. This fact was expected among the evaluated sectors, since the pioneer tree species constituted the first forest stratum of the environment to be restored at the beginning of the forest succession process.

The large number of pioneer species observed in the regenerating stratum in S1 (eight species), and S2 (16 species), evidences the difficulty in the substitution process. Or, more likely, a short period of time for forming a modified microenvironment suitable for occupation, by demanding species, as promoted by the occupation of the arboreal stratum (RODRIGUES et al., 2015). We also consider that there is environmental heterogeneity in the forest (with the opening of clearings being possible), mainly caused by the death of individuals, which makes the light arrival to the forest soil more intense and enables pioneer species present in the soil seed bank to germinate (MACIEL et al., 2004).

There were more species with zoochoric dispersion syndrome in the $\mathrm{S} 2$ sector, 15 species for the arboreal stratum $(55.6 \%)$ and 26 species for the regenerating stratum (68.4\%), compared to the other syndromes evaluated. According to Giehl et al. (2007), zoochory is the main dispersion form for Mixed Ombrophilous Forest; a fact reinforced by the obtained results. The sites under passive restoration have a close relationship with zoochoric species, meaning there is a great dependence of animals on this phytophysiognomy (FERREIRA et al., 2012; FERRACIN et al. 2013; SCARIOT et al., 2014; CIELO-FILHO; SOUZA, 2016).

The Shannon Index (H') indicated considerable species diversity, with values varying from 2.09 to 2.99 nats ind-1. These values are consistent with the variation found by Vibrans et al. (2011) for the Mixed Ombrophilous Forest of Santa Catarina, in environments under different successional stages (H' ranging from 2.85 to 2.90 nats ind $^{-1}$ ). Dalla Rosa et al. (2015) found values similar to those of the present study for a fragment with influence of forest plantations in the southern plateau of Santa Catarina. However, the highest values found by these authors refer to the arboreal stratum $\left(\mathrm{H}^{\prime}=3.2\right.$ nats ind $\left.^{-1}\right)$, while the highest values in the present study were found for the regenerating stratum. This may indicate the possibility of maintaining or even increasing the diversity in the future (RUSCHEL et al., 2009; RODRIGUES et al., 2015).

There was an increase in the values of H', J' and standardized richness of the adult stratum for the regeneranting in the S2 sector with the incorporation of species in more advanced stages in the regenerating stratum, thereby answering the second question of this study.

We considered that there is a possible presence of ecological dominance $\left(\mathrm{J}^{\prime}=0.69\right)$ in the adult stratum (Table 2) caused by the abundance of the Mimosa scabrella pioneer species. Occupation by this species was expected, since it is commonly found in high density in the initial phase of secondary Mixed Ombrophilous Forest formations (FERREIRA et al., 2017). As it is a species capable of promoting ecological facilitation or nucleation in restoring environments (REIS et al., 2014), M. scabrella was the species with the highest importance value in an evaluation performed by Ferreira et al. (2012), three years after the riparian forests began to expand.

Populations of M. scabrella tend to reduce the number of individuals gradually over time, from 13 to 20 years of forest (SCARIOT et al., 2014). Therefore, it is assumed that in the S2 sector (in forest succession since 2005), total substitution of the species has not yet occurred, occupying a large portion of the importance value of the S2 sector adult stratum, as observed in Figure 2. According to Ruschel et al. (2009), the decline or rise of the populations occur in the communities according to the forest's successional stage, meaning after the replacement

FLORESTA, Curitiba, PR, v. 48, n. 4, p. 523-534, out/dez. 2018

Stedille. L. I. B. et.al.

ISSN eletrônico 1982-4688

DOI: $10.5380 /$ rf.v48i4.55319 
of the initial species that currently compose the canopy of the forest under restoration, there will possibly be incorporation of species individuals of more advanced successional stages.

The NMDS ordering showed differences in the floristic-structural composition between the S1 and S2 sectors, with several species characterizing the arboreal stratum (Figure 3A), and the regenerating stratum (Figure 3B). The study developed by Scariot et al. (2014) corroborates this research, as it also revealed low floristic similarity among the evaluated fragments, including in sites under passive restoration and conserved environments. Fragments such as riparian forests in more advanced successional stages as well as the Legal Reserve are important propagule sources. However, for large areas, such as this farm (Figure 1), the arrival of propagules may occur differently, including from non-sampled areas such as areas outside the farm, which could partially explain the floristic distance found between the sectors.

In general, significant differences for the tree stratum were observed for most of the evaluated ecological indicators, showing that there are differences between the successional stages of the environments. Regarding the regenerating stratum and despite significant floristic-structural differences, similarities were observed in the ecological indicators such as standardized richness, H' and J', which suggests resilience of the area under restoration (S2) in detriment to possible connectivity with S1. Furthermore, it is assumed that natural regeneration presents heterogeneous behavior in the forest due to biotic and abiotic factors (SCARIOT et al. 2014; REIS et al., 2014).

According to Suding and Hobbs (2009), the gradual enrichment of ecosystems under restoration is done by new animal and plant species entering, which depends on a series of internal factors (competition, predation and facilitation) and external factors (flows in the landscape and regional set of species). These factors can result in different communities in terms of composition and structure, meaning that it is not intended for two environments to be identical, but rather that they are diverse enough that they can perpetuate themselves, allowing restoration to be part of a continuous dynamic process (REIS et al., 2014). Therefore, a decade after forest plantations being removed, the tree composition presents differences which are evidenced by the succession time. Regarding species diversity, there are similar values between the sector and the reference area, and the area under passive forest restoration process.

\section{CONCLUSIONS}

- After a decade in succession, the passive restoration showed to be efficient for enlarging the riparian forest located in the Mixed Ombrophilous Forest, with values of tree richness, diversity, evenness, number of individuals from later succession and zoochoric stages being maintained and incorporated from the arboreal to the regenerating stratum.

- The regenerating stratum of the forest under passive restoration, and the reference ecosystem did not show differences at diversity levels of tree species. This indicate that the evaluated restoration process allows environments in restoration to reach a level of composition and structure similar to the reference ecosystem over time.

\section{ACKNOWLEDGEMENTS}

The authors thank the State University of Santa Catarina by granting the master's degree scholarship to LIBS, the Foundation for Teaching, Research and Extension (FIEPE/CAV) and the Foundation for Support of Research and Innovation, Santa Catarina - Brasil (FAPESC) for the support. To PhD Roseli Lopes da Costa Bortoluzzi for identifying the Fabaceae species, PhD Cláudio Augusto Mondin for identifying the Asteraceae species, and to $\mathrm{PhD}$ Ana Carolina da Silva for the help with the dendrological identification of species, mainly those without reproductive structures (young plants).

\section{REFERENCES}

ALVARES, C. A.; LUIZ, S. J.; SENTELHAS, P. C.; GONÇALVES, J. L. M.; SPAROVEK G. Köppen's climate classification map for Brazil. Meteorologische Zeitschrift, Alemanha, v. 22, n. 6, p. 711-728, 2014.

BUDOWSKI, G. Distribution of tropical American rain forest species in the light of sucessional processes. Turrialba, Costa Rica, v. 15, n. 1, p. 40-42, 1965.

CAIN, S. A.; CASTRO, G. M. de O. Manual of vegetation analysis. New York: Harper, 1959, 325p.

CIELO-FILHO, R.; SOUZA, J.A.D. de. Assessing passive restoration of an Atlantic Forest site following a Cupressus lusitanica Mill. plantation clearcutting. Ciência Florestal, Santa Maria, v. 26, n. 2, p. 475-488, 2016. 
CONSELHO NACIONAL DE MEIO AMBIENTE- CONAMA. Resolução n 429 de 28 de fevereiro de 2011. Dispõe sobre a metodologia de recuperação das Áreas de Preservação Permanente - APP's. Diário Oficial da União, Brasília, DF, dois de março de 2011. Disponível em: <http://www.mma.gov.br/port/conama/legiabre.cfm?codlegi=644>. Acesso em: 09 jan. 2017.

DALlA ROSA, A. D.; SILVA, A. C. da; HIGUCHI, P.; GUIDINI, A. L.; SPIAZZI, F. R.; NEGRINI, M.; DJEISON, A. R.; BENTO, M. A.; GONÇALVES, D. A.; FERREIRA, T. de. S. Diversidade e guildas de regeneração de espécies arbóreas na borda de uma floresta nativa em contato com plantio de pínus. Floresta, Curitiba, v. 45, n. 2, p. 273 - 280, 2015.

EMPRESA BRASILEIRA DE PESQUISA AGROPECUÁRIA - EMBRAPA. Sistema brasileiro de classificação de solos. 3. ed. Brasília, 2013. 353 p.

EMER, C.; FONSECA, C. R. F. Araucaria Forest conservation: mechanisms providing resistance to invasion by exotic timber tress. Biol Invasions, v.13, n.1, p.189-202, jun. 2011.

FERRACIN, T. P.; MEDRI, P. S.; BATISTA, A. C. R.; MOTA, M. C.; BIANCHINI, E.; TOREZAN, J. M. D. Passive Restoration of Atlantic Forest Following Harvesting in Southern Brazil. Restoration Ecology, Washington, v. 21, n. 6, p. 770 - 776, 2013.

FERREIRA, P. I.; PALUDO, G. F.; CHAVES, C. L.; BORTOLUZZI, R. L. da C.; MANTOVANI, A. Florística e fitossociologia arbórea de remanescentes florestais em uma fazenda produtora de Pinus spp. Floresta, Curitiba, v. 42 , p. $783-794,2012$.

FERREIRA, P. I.; GOMES, J. P.; STEDILLE, L. I. B.; BORTOLUZZI, R. L. da C.; MANTOVANI, A. Dinâmica de bracatingais inequiâneos sob diferentes condições ambientais no Planalto Sul Catarinense. Floresta, Curitiba, v. 47 , p. $43-54,2017$.

FLORA DO BRASIL 2020. Flora do Brasil 2020: Algas, Fungos e Plantas. Disponível em: <http://floradobrasil.jbrj.gov.br/reflora/listaBrasil/PrincipalUC/PrincipalUC.do;jsessionid=4077D5909FAF0AE B0B2CA1D256C6E536> Acesso em: 23 abr. 2018.

GIEHL, E. L. H.; ATHAYDE, E. A.; BUDKE, J. C.; GESING, J. P. A.; EINSIGER, S. M.; CANTO-DOROW, T. S. Espectro e distribuição vertical das estratégias de dispersão de diásporos do componente arbóreo em uma Floresta Estacional no Sul do Brasil. Acta botanica brasilica, São Paulo, v. 21, n. 1, p. 137 - 145, 2007.

GRESSLER, E.; PIZO, M. A.; MORELLATO, L. P. C. Polinização e dispersão de sementes em Myrtaceae do Brasil. Brazilian Journal of Botany, v.29, n.4, p. 509-530, 2006.

LETCHER, S. G.; CHAZDON, R. L. Rapid recovery biomass, species richness, and species composition in a forest chronosequence in Northeastern Costa Rica. Biotropica, Malden, v. 41, n. 5, p. 608 - 617, 2009.

MACIEL, M. de N. M.; WATZLAWICK, L. F.; SCHOENINGER, E. R. YAMAJI, F. M. Classificação ecológica das espécies arbóreas. Revista Acadêmica: ciências agrárias e ambientais, Curitiba, v.1, n. 2, p. 69 - 78, 2003.

MELI, P.; HOLL, K. D.; REY BENAYAS, J. M.; JONES, H. P.; JONES, P. C.; MONTOYA, D.; MATEOS, D. M. A global review of past land use, climate, and active vs. passive restoration effects on forest recovery, Plos One, India, v. 12, n. 2, p. 1 - 17, 2017.

R DEVELOPMENT CORE TEAM. R: A language and environment for statistical computing. Disponível em: $<$ (http://www.Rproject.org)> Acesso em:18 nov. 2016.

REIS, A.; BECHARA, F. C.; TRES, D. R.; TRENTIN B. E. Nucleação: concepção biocêntrica para a restauração ecológica. Ciência Florestal, Santa Maria, v. 24, n. 2, p. 509 - 519, 2014.

REIS, A.; TRES, D. R.; SCARIOT, E. C. Restauração na Floresta Ombrófila Mista através da sucessão natural. Pesquisa Florestal Brasileira, Colombo, n. 55, p. 67 - 73, 2007.

REITZ, P: KLEIN, R.M.; REIS, A. Projeto Madeira- Santa Catarina. Herbário Barbosa Rodrigues, Florianópolis: Lunardelli. 1978, 320 p.

RODRIGUES, R.R.; GANDOLFI, S.; BRANCALION, P.H.S. Restauração florestal. São Paulo: Oficina de Textos, 2015, 430 p.

RUSCHEL, A. R.; MANTOVANI, M.; REIS, M. S. dos; NODARI, R. O. Caracterização e dinâmica de duas fases sucessionais em floresta secundária da Mata Atlântica. Árvore, Viçosa, v. 33, n. 1, p. 101-115, 2009.

FLORESTA, Curitiba, PR, v. 48, n. 4, p. 523-534, out/dez. 2018

Stedille. L. I. B. et.al.

ISSN eletrônico 1982-4688

DOI: $10.5380 /$ rf.v48i4.55319 
SCARIOT, E. C.; TRES, D. R.; REIS, A. Componente arbustivo-arbóreo de matas ciliares em restauração e remanescentes naturais inseridos em matriz silvícola, Rio Negrinho, SC. Ciência Florestal, Santa Maria, v. 24, n. 2, p. 401 - 412, 2014.

SCHORN, L. A.; FENILli, T. A. B.; KRÜGER, A.; PELlENS, G. C.; BUDAG, J. J.; NADOLNY, M. C. Composição do banco de sementes no solo em áreas de preservação permanente sob diferentes tipos de cobertura. Floresta, Curitiba, v. 43, n. 1, p. 49 - 58, 2013.

SIMINSKI, A.; FANTINI, A. C.; GURIES, R. P.; RUSCHEL, A. R.; REIS, M. S dos. Secondary Forest sucession in the Mata Atlântica, Brazil: Floristic and Phytosociological Trends. Ecology, Washington, v. 2011, p.1 - 19, 2011.

SUDING, K. N.; HOBBS, R. J. Models of ecosystem dynamics as frameworks for restoration ecology. In: HOBBS, R. J.; SUDING, K. N. and Society for Ecological Restoration International. New Models for Ecosystem Dynamics and Restoration. Island Press: New York, 2009, 366 p.

SUGANUMA, M. S.; ASSIS, G. B.; MELO, A. C.G.; DURIGAN, G. Ecossistemas de referência para restauração de matas ciliares: existem padrões de biodiversidade, estrutura florestal e atributos funcionais? Árvore, Viçosa, v. 37, n.5, p. 835-847, 2013.

VAN DER PIJL, L. Principles of dispersal in higher plants. Berlim: Springer; 1972.

VIBRANS, A.; SEVEGNANI, L.; UHLMANN, A. C.; SCHORN, L. A.; SOBRAL, M.; LINGNER D. V.; BROGNI, E.; KLEMZ, G., GODOY, M. B.; VERDI, M. Structure of Mixed Ombrophyllous Forests with Araucaria angustifolia. Biologia Tropical, Costa Rica, v. 59, p. 1371 - 1387, 2011. 